\title{
The effect of stand species composition on water storage capacity of the organic layers of forest soils
}

\author{
Anna Ilek $\cdot$ Jarosław Kucza $\cdot$ Małgorzata Szostek
}

Received: 2 May 2014/Revised: 21 August 2014/Accepted: 4 September 2014/Published online: 14 September 2014

(C) The Author(s) 2014. This article is published with open access at Springerlink.com

\begin{abstract}
The dynamics of litterfall and its quantitative differentiation in stands with different species composition suggest that the origin of the organic matter accumulated in the organic horizons of forest soils affects their physical properties, and thus, their ability to retain rainwater. The main aim of the study was to determine the physical properties, the degree of decomposition and capillary capacity of individual ectohumus sublevels of mountain forest soils, formed under fir stands (Abies alba Mill.) and beech stands (Fagus sylvatica L.), and to compare them with the physical and retention properties of the organic horizons of spruce stands [Picea abies (L.) H. Karst], as determined by Kucza (2007). The study was conducted on soil monoliths, sampled in a way that allowed preserving their natural structure. For individual ectohumus sublevels contained in the monoliths, the content and degree of decomposition of organic matter, bulk density, total porosity and capillary capacity were determined. It has been shown that the capillary capacity of the litter layer (Ol) differed significantly between beech, fir and spruce
\end{abstract}

The results presented in this paper have been partly referenced at the IV International 'Forest and Water' Conference in Smardzewice (Poland, 2013).

Communicated by Agustin Merino.

\section{A. Ilek $(\bowtie) \cdot$ J. Kucza}

Department of Forest Engineering, Faculty of Forestry, University of Agriculture in Cracow, Al. 29 Listopada 46, 31-425 Kraków, Poland

e-mail: a.ilek@wp.pl

\section{Szostek}

Department of Soil Science, Environment Chemistry and Hydrology, University of Rzeszow, ul. Ćwiklińskiej 2/D3, 35-601 Rzeszow, Poland stands, assuming average values equal to $1.60( \pm 0.10)$, $2.76( \pm 0.11)$ and $4.44( \pm 0.10) \mathrm{mm} \mathrm{H}_{2} \mathrm{O}$ in the layer of $1 \mathrm{~cm}$, respectively. In the case of detritus (Ofh) horizons, the smallest water storage capacity characterized beech stands, wherein the capillary capacity was approximately $1.39 \mathrm{~mm}$ lower than in fir stands and over twice lower as compared to spruce stands.

Keywords Forest hydrology · Capillary capacity · Organic horizons of forest soil - Abies alba Mill. . Fagus sylvatica L. · Picea abies (L.) H. Karst

\section{Introduction}

Apart from minerals, organic matter is one of the fundamental and characteristic components of forest soils. It affects many physical and chemical properties of soils as well as the direction and intensity of biochemical processes occurring in them (Tobiašová 2011). It is a major determinant of natural soil fertility and biomass production, and also plays an important role both in the water cycle and in water quality (Gonet 2007).

The main source of organic matter in forest soils is the aboveground plant litterfall from trees, shrubs and undergrowth as well as the dying subsurface plant components (Gonet et al. 2007). Litterfall is one of the most important elements in the process of matter circulation in forest ecosystems (Kowalkowski 1994). It is continuous, but it is characterized by pronounced fluctuations depending on the season and is dependent on the weather conditions, the terrain, the trophic conditions of the ecosystem and the plant community structure (Parzych and Trojanowski 2009; Zhang et al. 2009; Niewinna 2010). Numerous studies indicate that the amount of litterfall getting to the soil also 
depends on the species composition of the stand and on its age. For example, Simmons (1974) reports that the litterfall of fir taiga ranges from 2.5 to $3.0 \mathrm{t} / \mathrm{ha}$. Jonczak (2013) found that litterfall in a 120-year-old beech stand ranges from 2.79 to $5.40 \mathrm{t} / \mathrm{ha}$, with the largest values appearing in its seminal years. In turn, Binkley (1995) states that the mass of litterfall in 40-year-old stands of $P$. strobus, $P$. tremuloides, $P$. glauca, $P$. resinosa and $P$. banksiana is, respectively, 2.90, 3.98, 5.48, 6.18 and 5.75 t/ha. The quantity and quality of organic debris affects the morphology and properties of soils as well as the nutrition of plants and heterotrophic organisms that inhabit the soil (Dziadowiec et al. 2004). Annual litterfall allows for the formation of specific forest soil humus horizons with characteristic vertical variation of physical properties in the soil profile (Maciaszek and Zwydak 1996). The top layer of forest soils is formed by the organic layer $(\mathrm{O})$. Depending on the advancement of the organic matter decomposition processes, this layer contains the following sublevels (Dziadowiec et al. 2004): (1) litter (Ol)—consisting of almost unchanged plant debris in the first phase of its processing, with tissue structures preserved; (2) the fermentation sublevel (Of) - consisting of strongly disintegrated and discolored material, the excrements of the small soil fauna and formless humus; (3) the humification sublevel (Oh) — containing mainly formless humus and a considerable admixture of mineral material; (4) the detritus sublevel (Ofh) — consisting of strongly disintegrated and discolored material, usually containing a considerable admixture of mineral material.

The rate of organic matter decomposition is very strongly related to the quality of the material being decomposed and the quantity of organisms responsible for decomposition (Kodešová et al. 2007; Coûteaux et al. 2002). Thanks to a reduced share of the decompositionresistant fraction (mainly lignin), the plant material from deciduous trees is more easily absorbed by microorganisms, and thus more rapidly degraded and mineralized in comparison with the material from coniferous trees (Olszowska 2011). The rate of mineralization processes is also determined by the morphology of plant residue. Material covered with cuticle, with leaves hard and difficult to wet, is slower to mineralize (Johansson 1994). Also, a large variation in the bulk density of dry foliage, from $0.24 \mathrm{~g} \cdot \mathrm{cm}^{-3}$ for oak to $0.50 \mathrm{~g} \cdot \mathrm{cm}^{-3}$ for spruce (Suliński 1993), shows the diversity of the initial material before the beginning of the decomposition process (Kucza 2003a).

Hydrological importance of organic horizons of forest soils is the subject of research conducted both in field and laboratory (Bernard 1963; Golding and Stanton 1972; Naeth et al. 1991; Schaap et al. 1997; Kucza and Suliński 2000; Laurén and Mannerkoski 2001; Kucza 2003a, b, c;
Kiss et al. 2005; Raaflaub and Valeo 2008, 2009; Keith et all. 2010a, b; Park et al. 2010). However, in comparison with the extensive literature on the interception properties of plants, relatively few works concern the hydrological properties of organic soil horizons. They focus on the importance of the organic cover in the protection of soil against erosion, evaporation of the underlying mineral layers as well as increasing the infiltration and retention properties of soil (Gerrits et al. 2006; Sharafatmandrad et al. 2010; Neris et al. 2013). Some authors also indicate that the water stored in the organic soil horizons may be an important source of water for plants (Sharratt 1997; Leuschner 1998; Greiffenhagen et al. 2006).

The water storage capacity of the organic horizons of forest soils is affected by a number of factors, such as the type and degree of decomposition of organic matter (Zhang et al. 2006; Kucza 2007; Tsiko et al. 2012) and the wettability of the soil material (Prusinkiewicz and Kosakowski 1986). Putuhena and Cordery (1996), Sato et al. (2004) and $\mathrm{Li}$ et al. (2013) found that the water content of the forest litter has a linear relationship with respect to its mass. Kucza and Suliński (2000) found that the ability of forest soil organic horizons (containing litter and the Of and $\mathrm{Oh}$ layers) to shrink and swell under the influence of drying and wetting is of particular importance in the shaping of the water storage capacity of these horizons. Sato et al. (2004) showed that with increased levels of rain, water retention capabilities of litter grow. Also, Li et al. (2013), who examined the litter of $Q$. variabilis, A. truncatum, P. tabulaeformis and $P$. orientalia, stated that regardless of the species, with an increase in rainfall intensity, the interception capabilities of the litter grow. Kucza (2007), when studying the organic horizons of spruce stands, stated that the increment of water reserves after single rainfall to a large extent depends on the initial water reserve in these horizons. Grelewicz and Plichta $(1983,1985)$ showed that the influence of the initial water reserve on the amount of the rainwater retained depends on the degree of humification of organic matter. In turn, Kucza (2003b) demonstrated that the amount of water retained by the organic horizons of forest soils (containing litter and the Of and $\mathrm{Oh}$ layers) also depends on their bulk density. That author also stated that the time between successive rainfalls is an important factor influencing the increment of water reserves in the organic horizons. Any longer interval between rainfalls is beneficial for increasing the capacity of water retention by the organic layers of forest soils.

The dynamics of litterfall and its quantitative differentiation in stands with a different species composition suggest that the origin of the organic matter accumulated in the organic horizons of forest soils affects their physical properties, and thus, their ability to retain rainwater. 


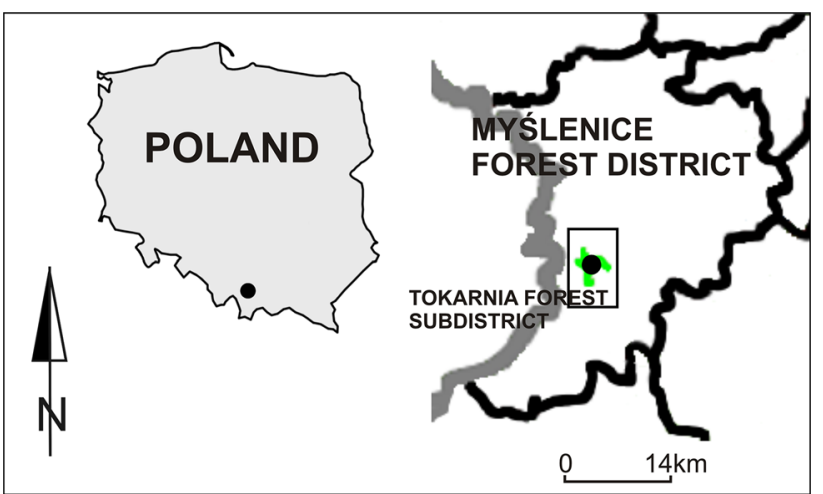

Fig. 1 Location of the study area

Accordingly, the aims of the present study are as follows:

1. to determine the physical properties, the degree of decomposition and capillary capacity of individual ectohumus sublevels of forest soils, formed under fir stands (Abies alba Mill.) and beech stands (Fagus sylvatica $\mathrm{L}$.), and compare them with the physical and retention properties of the organic horizons of spruce stands [Picea abies (L.) H. Karst], as determined by Kucza (2007);

2. to analyze the impact of the physical properties (bulk density and total porosity) and the degree of decomposition of organic matter on the capillary capacity of the organic horizons of beech, fir and spruce stands.

\section{Materials and methods}

The study area

The study was conducted in Tokarnia Forest Sub-District, located within Myślenice Forest District in south-central Poland (Fig. 1). In terms of the natural-forest regionalization, the research area is located in the VIII Carpathian Province, the Beskid Makowski and Wyspowy Region in the Beskid Makowski Mezoregion (Trampler et al. 1990). The research was done in ten selected research plots located in fir stands (A. alba Mill.) and ten plots located in

Table 1 Characteristics of research plots

\begin{tabular}{|c|c|c|c|c|c|c|c|c|c|c|c|c|c|}
\hline \multirow[t]{2}{*}{ Plot symbol } & \multirow[t]{2}{*}{ Stand } & \multirow[t]{2}{*}{ Age (years) } & \multirow[t]{2}{*}{$\mathrm{DBH}(\mathrm{cm})$} & \multirow[t]{2}{*}{$H(\mathrm{~m})$} & \multirow[t]{2}{*}{ Altitude } & \multirow[t]{2}{*}{ Exposure } & \multirow[t]{2}{*}{$I\left(^{\circ}\right)$} & \multicolumn{2}{|c|}{ Thickness $(\mathrm{cm})$} & \multicolumn{2}{|c|}{$\mathrm{pH} \mathrm{H} \mathrm{H}_{2} \mathrm{O}$} & \multicolumn{2}{|c|}{$\mathrm{pH} \mathrm{KCl}$} \\
\hline & & & & & & & & Ol & Ofh & $\mathrm{Ol}$ & Ofh & Ol & Ofh \\
\hline $\mathrm{T} 1$ & Fir & 45 & 21 & 17 & 730 & $\mathrm{~N}$ & 18 & 0.58 & 1.48 & 4.07 & 4.15 & 3.68 & 3.59 \\
\hline $\mathrm{T} 2$ & Fir & 30 & 10 & 8 & 680 & $\mathrm{~N}$ & 14 & 0.21 & 0.70 & 4.40 & 4.36 & 4.03 & 3.94 \\
\hline $\mathrm{T} 3$ & Fir & 110 & 51 & 31 & 590 & NW & 20 & 0.28 & 0.80 & 4.95 & 5.12 & 4.67 & 4.72 \\
\hline $\mathrm{T} 4$ & Fir & 90 & 41 & 29 & 570 & $\mathrm{NE}$ & 20 & 0.68 & 1.14 & 4.51 & 4.32 & 4.24 & 3.83 \\
\hline G5 & Fir & 40 & 18 & 12 & 515 & $\mathrm{NE}$ & 15 & 0.55 & 0.87 & 4.29 & 4.52 & 4.06 & 4.14 \\
\hline G6 & Fir & 40 & 21 & 15 & 520 & $\mathrm{NE}$ & 12 & 0.72 & 0.57 & 4.37 & 4.58 & 4.17 & 4.18 \\
\hline R7 & Fir & 35 & 12 & 13 & 810 & W & 10 & 0.23 & 0.64 & 4.03 & 4.13 & 3.69 & 3.45 \\
\hline $\mathrm{J} 8$ & Fir & 50 & 25 & 23 & 430 & $\mathrm{~N}$ & 18 & 0.56 & 0.91 & 4.50 & 4.52 & 4.18 & 4.15 \\
\hline J9 & Fir & 55 & 28 & 24 & 770 & $\mathrm{~N}$ & 22 & 0.35 & 0.56 & 4.29 & 4.01 & 3.85 & 3.27 \\
\hline $\mathrm{J} 10$ & Fir & 120 & 46 & 30 & 690 & SE & 18 & 0.98 & 2.82 & 4.31 & 4.19 & 3.94 & 3.64 \\
\hline B1 & Beech & 65 & 27 & 25 & 690 & SW & 5 & 0.97 & 1.49 & 4.91 & 4.92 & 4.73 & 4.62 \\
\hline B2 & Beech & 18 & - & 7 & 520 & E & 5 & 0.77 & 1.95 & 5.39 & 5.12 & 5.13 & 4.92 \\
\hline B3 & Beech & 110 & 43 & 30 & 710 & $\mathrm{~S}$ & 10 & 0.91 & 3.38 & 4.95 & 4.15 & 4.63 & 3.50 \\
\hline B4 & Beech & 115 & 44 & 31 & 765 & $\mathrm{~S}$ & 15 & 0.38 & 1.09 & 5.02 & 4.82 & 4.59 & 4.23 \\
\hline B5 & Beech & 80 & 36 & 29 & 700 & $\mathrm{NE}$ & 25 & 0.59 & 0.59 & 4.85 & 4.47 & 4.58 & 4.31 \\
\hline B6 & Beech & 10 & - & 5 & 610 & W & 15 & 0.49 & 0.86 & 4.88 & 4.70 & 4.59 & 4.52 \\
\hline B7 & Beech & 120 & 45 & 32 & 710 & $\mathrm{~S}$ & 25 & 0.37 & 1.62 & 5.23 & 5.05 & 5.02 & 4.67 \\
\hline B8 & Beech & 85 & 31 & 27 & 720 & $\mathrm{~S}$ & 25 & 0.72 & 2.97 & 5.24 & 3.75 & 4.87 & 3.31 \\
\hline B9 & Beech & 55 & 24 & 22 & 570 & SE & 15 & 0.35 & 1.44 & 4.90 & 4.79 & 4.48 & 4.41 \\
\hline B10 & Beech & 115 & 46 & 32 & 640 & W & 15 & 0.44 & 0.90 & 4.73 & 4.86 & 4.35 & 4.38 \\
\hline
\end{tabular}

Age, DBH and $H$ according to PUL (2008)

DBH - the average breast-height diameter of the stand, $H$ - the average height of the stand, $I$ - slope 
beech stands ( $F$. sylvatica L.), differing in age. The soils of all examined stands were formed out of magura sandstone rock waste and classified as acid brown soils. The characteristics of each research plot are presented in Table 1 .

\section{Sampling of research material}

Research material in the form of soil monoliths composed of successive, naturally formed organic horizons of mountain forest soils was collected in the period from September to November 2012. Soil monoliths were collected according to the method proposed by Kucza (2003a), by cutting them using steel frames in the shape of prisms with an area of $324 \mathrm{~cm}^{2}$ and a height of 10 or $12 \mathrm{~cm}$. Due to the presence, in ectohumus sublevels, of undecayed organic debris of different dimensions (needles, leaves, twigs, roots), which could form a lever that might destroy the structure of these horizons, the cutting of the monolith was done by loading the upper soil surface with a wooden plate with a surface area corresponding to that of the steel frames and stabilized manually. The monoliths were sampled at the distance of about $1.5 \mathrm{~m}$ from tree stems, within the range of tree crowns. In young stands with high density (up to 30 years), the monoliths were sampled between neighboring trees. In the place of sampling of a given monolith, from particular ectohumus sublevels collected were also samples for the determination of the degree of organic matter decomposition (described below) and the reaction using the potentiometric method in water and in $1 \mathrm{M}$ solution of $\mathrm{KCl}$ (Elmetron $\mathrm{CX}-731 \mathrm{pH}$-meter) (Table 1).

From each of 15 research plots was collected a single monolith containing the litter layer $(\mathrm{Ol})$ and the detritus layer (Ofh), while from each of the remaining 5 plots (J8, J10, B2, B3 and B6) were collected two monoliths. The study was performed on a total of 25 soil monoliths; 12 of them came from fir stands and 13 from beech stands. Additional monoliths sampled from the above-mentioned plots were used to conduct additional laboratory experiments on the dynamics of rainfall retention by the organic horizons of forest soils. The results of those experiments will be the subject of a separate study. It should also be noted that the research on the organic horizons of spruce stands (Kucza 2007) whose results are used in the present study was conducted on the soil material sampled according to the above-mentioned procedures.

\section{Laboratory tests}

\section{Measurement of the capillary capacity}

According to Kucza (2003c), the soil capillary capacity, determined in the state of long-term and maximum storage
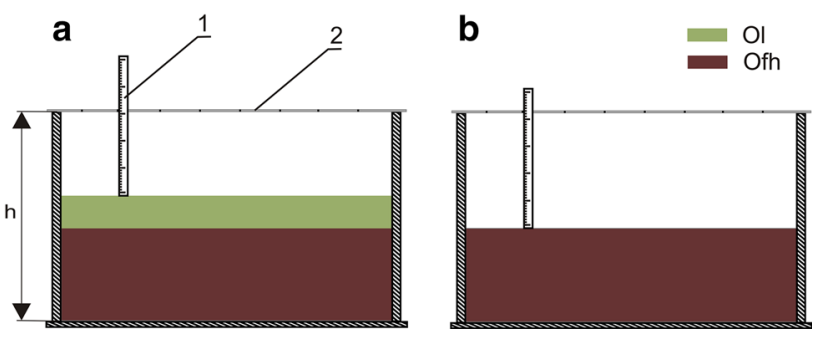

Fig. 2 A measurement diagram of a thickness of the whole ectohumus and $\mathbf{b}$ of individual ectohumus sublevels included in a given monolith, where $h$-height of the frame, Ol-litter horizon, Ofh-detritus horizon, 1-gauge, 2-strip defining the reference level of depth measurements

capacity, is the value defining the maximum capacity of the water reservoir of the soil medium. Therefore, capillary capacity $P_{\mathrm{k}}$ was determined by placing individual monoliths in containers with water for the period of 7-10 days, where in the initial stage of soaking (2-3 days), the monoliths were slowly filled with distilled water by gradually raising the level of water in the containers. The water in the containers was changed every 2 days so as to prevent rotting. The capillary capacity of the organic horizons of spruce stands was determined in the same way (Kucza 2007). The adopted methodology of capillary capacity examination with the samples being immersed in water was related to the results of research on the time of water absorption by organic matter carried out by Kucza and Urbaś (2005). The authors showed that, depending on the degree of decomposition, single organic matter particles need even several days to reach the state of maximum swelling and filling with water.

After the removal of a given monolith from the water and completion of the gravity draining process (lasting between 2 and $4 \mathrm{~h}$ ), under conditions of eliminating the surface evaporation, the monolith was weighed in order to capture the total ectohumus weight $(\mathrm{O})$ in the state of maximum storage capacity. Then, the monolith was divided into individual sublevels included in it in order to determine their physical and retention properties. The division of a given monolith was started by determining the thickness of the entire ectohumus, as depicted schematically in Fig. 2a, by measuring the average distance between the upper edge of the frame having a known height $h$ and the surface of the monolith. Then, the layer of the litter $(\mathrm{Ol})$ was removed, and the remainder of the monolith with the Ofh layer was again weighed and measured (Fig. 2b). The weight difference between the ectohumus (O) and the detritus layer (Ofh) allowed for obtaining the weight of the $\mathrm{Ol}$ layer in the state of the maximum water storage capacity. The thickness of that level was calculated analogously. The average height $H_{\mathrm{p}}$ of the discrete soil layers of the examined monoliths was the 
basis for calculating their volume $V$. In accordance with the principle adopted by Kucza (2007), the volume $V$ of individual organic layers, included in the examined monoliths, determined in the state of full wetting, was adopted as the basis for the calculation of all physical properties analyzed in the present study.

The capillary capacity of the ectohumus (O) and its different sublevels (Ol and Ofh), expressed in millimeters of water in the layer with the thickness of $1 \mathrm{~cm}$, were calculated by the formula:

$P_{\mathrm{k}}=(v / V) \times 10$

where $P_{\mathrm{k}}$ is the capillary capacity of a given soil layer ( $\mathrm{mm}$ $\mathrm{H}_{2} \mathrm{O}$ in the layer of $\left.1 \mathrm{~cm}\right) ; v$ is the water volume $\left(\mathrm{cm}^{3}\right)$ calculated (assuming the water density equal to $1 \mathrm{~g} \cdot \mathrm{cm}^{-3}$ ) from the difference between the weight of a given soil layer in the state of maximum storage capacity and the dry mass determined after drying the soil layer in the temperature of $105{ }^{\circ} \mathrm{C} ; V$ is the volume of a soil layer, defined in its maximum water storage capacity $\left(\mathrm{cm}^{3}\right)$.

The expression of capillary capacity in balance units ( $\mathrm{mm} \mathrm{H}_{2} \mathrm{O}$ in the layer of $1 \mathrm{~cm}$ ) allows for its direct application in the calculation of the water balance of forest areas, whose components (precipitation, evotranspiration) are also expressed in such units.

\section{Organic matter and the degree of advancement of its decay processes}

The organic matter content $C_{\mathrm{o}}$ of the various ectohumus sublevels from the examined stands was determined with the method of loss during roasting, by burning samples in a muffle furnace at $550{ }^{\circ} \mathrm{C}$ for the period lasting from 8 to $10 \mathrm{~h}$. The content of organic matter $C_{\mathrm{o}}$, which is the mass share of organic particles in the tested samples, was determined using conversions of reduction, taking into account the proportion of the ash parts of organic matter remaining in the sample after burning. The basis of these calculations was the results of loss during the roasting of pure beech and fir organic matter, which included needles, leaves, twigs and roots. For the reduction, the following dependence was used: $100 \%$ of fir organic matter $=97.54 \%$ loss during the roasting and $100 \%$ of the beech organic matter $=96.64 \%$ loss during the roasting. The content of organic carbon $\mathrm{C}$ was determined using the Tiurin method, and total nitrogen $\mathrm{N}$ was determined using the Kjeldahl method, in the Kiej-Fos automatic 16210 set, for individual ectohumus sublevels of the examined monoliths.

The degree of organic matter decomposition was determined by means of the $W_{\mathrm{NC}}$ decomposition index in the following form (Kucza and Urbaś 2005):
$W_{\mathrm{NC}}=(\mathrm{N} / \mathrm{C}) \times 1000$

The $W_{\mathrm{NC}}$ index was used to measure the degree of decomposition of organic matter contained in the litter and detritus layers, mainly due to the increase in its numerical values along with the advance of degradation processes (Kucza and Urbaś 2005).

\section{Bulk and specific density, and total porosity}

In the present study, bulk density $\rho_{\mathrm{d}}\left(\mathrm{g} \cdot \mathrm{cm}^{-3}\right)$ is understood as the ratio of dry mass $M_{\mathrm{s}}(\mathrm{g})$ of a given soil layer to its maximum volume $V\left(\mathrm{~cm}^{3}\right)$, defined at the time of having the full capillary capacity. It was expressed by the formula:

$\rho_{\mathrm{d}}=M_{\mathrm{s}} / V$

Specific density $\rho_{\mathrm{s}}\left(\mathrm{g} \cdot \mathrm{cm}^{-3}\right)$ of a given ectohumus sublevel (Ol, Ofh) was determined on the basis of the organic matter content $C_{\mathrm{o}}$ (\% wt.) in that layer, according to the formula developed by Ilek (2014):

$\rho_{\mathrm{s}}=2.6434-0.0209 \times C_{\mathrm{o}}+0.0001 \times C_{\mathrm{o}}^{2}$

On the basis of bulk density $\rho_{\mathrm{d}}$ and specific density $\rho_{\mathrm{s}}$, total porosity TP of particular ectohumus sublevels was calculated according to the formula:

$\mathrm{TP}=\left(\rho_{\mathrm{s}}-\rho_{\mathrm{d}}\right) / \rho_{\mathrm{s}}$

Data analysis

All statistical analyses were conducted with STATISTICA 10 (StatSoft 2011). The paper analyzes the relationship of capillary capacity with the physical properties, the decomposition index and the botanical origin of organic debris being part of particular sublevels of beech, fir and spruce ectohumus. Analyses were carried out using the multiple regression method. For calculation purposes, in the models of bulk density $\rho_{\mathrm{d}}$ (Eq. 8) and capillary capacity $P_{\mathrm{k}}$ (Eqs. 9-11), individual species were introduced as artificial variables, transforming them into two dummy variables: Fir and Beech. Spruce organic matter was adopted as an auxiliary group, constituting a reference group in the interpretation of the model parameters. Collinearity of the variables was evaluated by the variance inflation factor (VIF):

$\mathrm{VIF}_{j}=1 /\left(1-R_{j}^{2}\right)$

where $R_{j}^{2}$ is the coefficient of determination of variable $X_{j}$ for other explanatory variables included in the model.

The selection of the best model is based on the standard error of the estimate, the share of variance explained by the regression model $\left(R_{\text {adj }}^{2}\right)$, the distribution of residual values and the scatter of residual values versus values predicted by regression analysis. 
Table 2 Statistics of the content of: organic carbon $\mathrm{C}$ (\%) and total nitrogen $\mathrm{N}(\%)$ of the litter $(\mathrm{Ol})$ and the detritus (Ofh) horizons comprised in the fir and beech monoliths

$S D$ standard deviation, $C V$ coefficient of variation

Fig. 3 The range of variation of a-organic matter content $C_{\mathrm{o}}$ and $\mathbf{b}$-index decomposition index $W_{\mathrm{NC}}$ in particular ectohumus sublevels $(\mathrm{Ol}$ and Ofh), contained in the soil monoliths obtained from beech (F. sylvatica), fir (A. alba) and spruce (P. abies) stands

\begin{tabular}{lllllllllr}
\hline Variables & Horizon & Species & Mean & Median & SE & SD & Min & Max & CV (\%) \\
\hline C & Ol & Fir & 62.01 & 62.31 & 0.74 & 2.46 & 58.22 & 65.58 & 3.96 \\
& & Beech & 56.52 & 56.78 & 0.52 & 1.87 & 53.35 & 59.06 & 3.32 \\
& \multirow{2}{*}{ Ofh } & Fir & 50.37 & 52.34 & 1.76 & 5.85 & 35.00 & 56.01 & 11.62 \\
& & Beech & 52.28 & 54.19 & 1.57 & 5.43 & 37.89 & 56.73 & 10.39 \\
$\mathrm{~N}$ & \multirow{2}{*}{ Ol } & Fir & 1.13 & 1.07 & 0.06 & 0.20 & 0.86 & 1.48 & 18.02 \\
& & Beech & 1.45 & 1.44 & 0.03 & 0.13 & 1.30 & 1.77 & 8.68 \\
& \multirow{2}{*}{ Ofh } & Fir & 1.64 & 1.65 & 0.05 & 1.18 & 1.41 & 1.96 & 10.72 \\
& & Beech & 1.77 & 1.77 & 0.04 & 0.15 & 1.41 & 1.98 & 8.69 \\
\hline
\end{tabular}
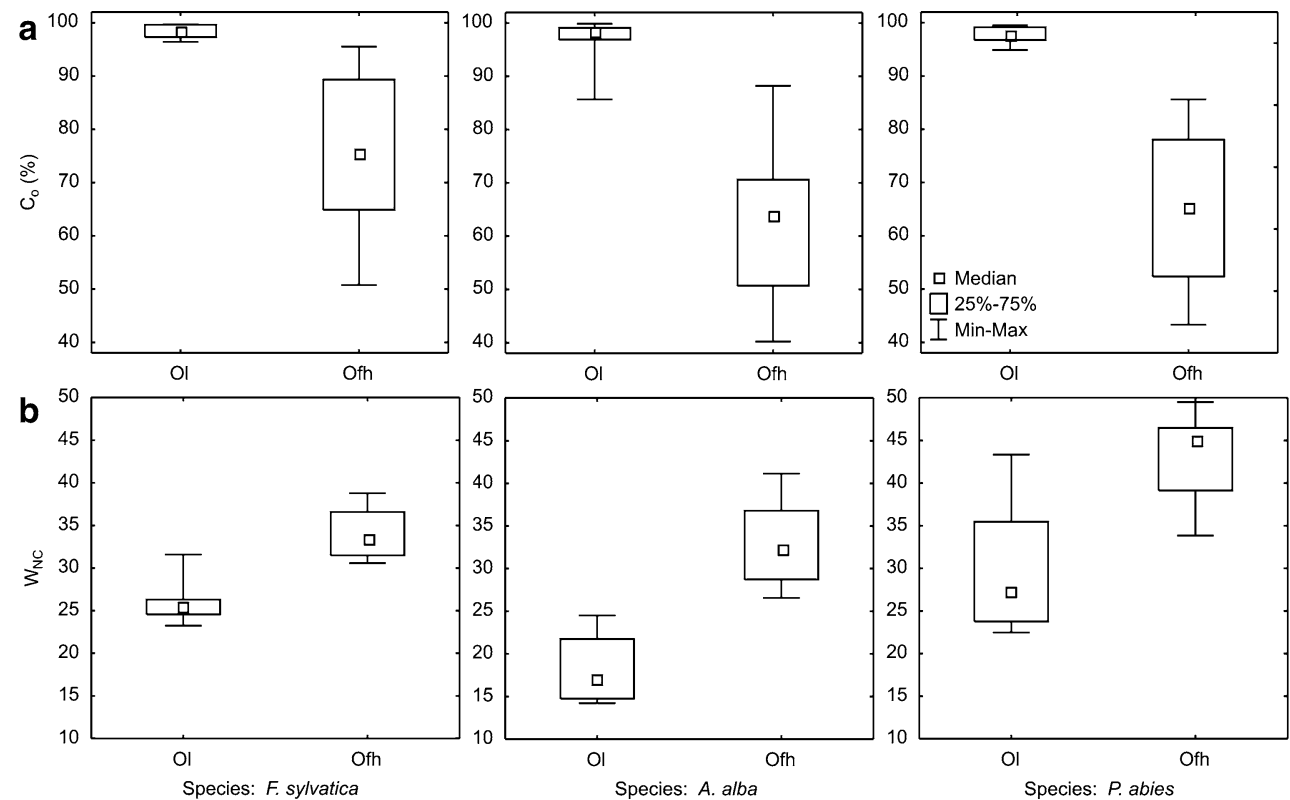

\section{Results and discussion}

The content and state of organic matter decomposition

The statistics of organic carbon content $C$ and total nitrogen $N$, determined for the $\mathrm{Ol}$ and Ofh horizons of beech and fir stands, is juxtaposed in Table 2. The distribution of variability of organic matter content $C_{\mathrm{o}}$ and the decomposition index $W_{\mathrm{NC}}$ of the $\mathrm{Ol}$ and Ofh horizons of the above-mentioned stands, in comparison with the organic horizons of spruce stands (Kucza 2007), are illustrated in Fig. 3.

The $\mathrm{Ol}$ and Ofh horizons of all studied stands differed significantly in terms of organic matter content $C_{\mathrm{o}}$ and the degree of its decomposition (Fig. 3a, b). Organic matter content $C_{\mathrm{o}}$ in the $\mathrm{Ol}$ horizons of all species remained at a similar level (Fig. 3a). In turn, the content of organic matter in the Ofh horizons of beech stands was on average 13 and $10 \%$ greater in comparison with the corresponding layers in the spruce and fir stands.
It was found that the fir litter was characterized by a lower advancement of decomposition processes in comparison with beech and spruce litter (Fig. 3b). Decomposition index $W_{\mathrm{NC}}$ of the detritus horizons (Ofh) of beech and fir stands was at a similar level. In turn, the decomposition index $W_{\mathrm{NC}}$ of the Ofh horizons of spruce stands was on average ten and nine higher in comparison with the Ofh horizons of fir and beech stands, which indicates a greater advancement of decomposition processes in these horizons in spruce stands (Fig. 3b).

Bulk density and total porosity

The distribution of variability of bulk density $\rho_{\mathrm{d}}$ and total porosity TP of particular beech and fir ectohumus sublevels, as compared to the organic horizons of spruce stands (Kucza 2007), is illustrated in Fig. 4.

Among all species tested, both bulk density $\rho_{\mathrm{d}}$ and total porosity TP differed significantly between the $\mathrm{Ol}$ and $\mathrm{Ofh}$ 
Fig. 4 The range of variation of a-bulk density $\rho_{\mathrm{d}}$ and $\mathbf{b}$ - total porosity $\mathrm{TP}, \mathrm{Ol}$ and $\mathrm{Ofh}$ horizons of beech, fir and spruce stands
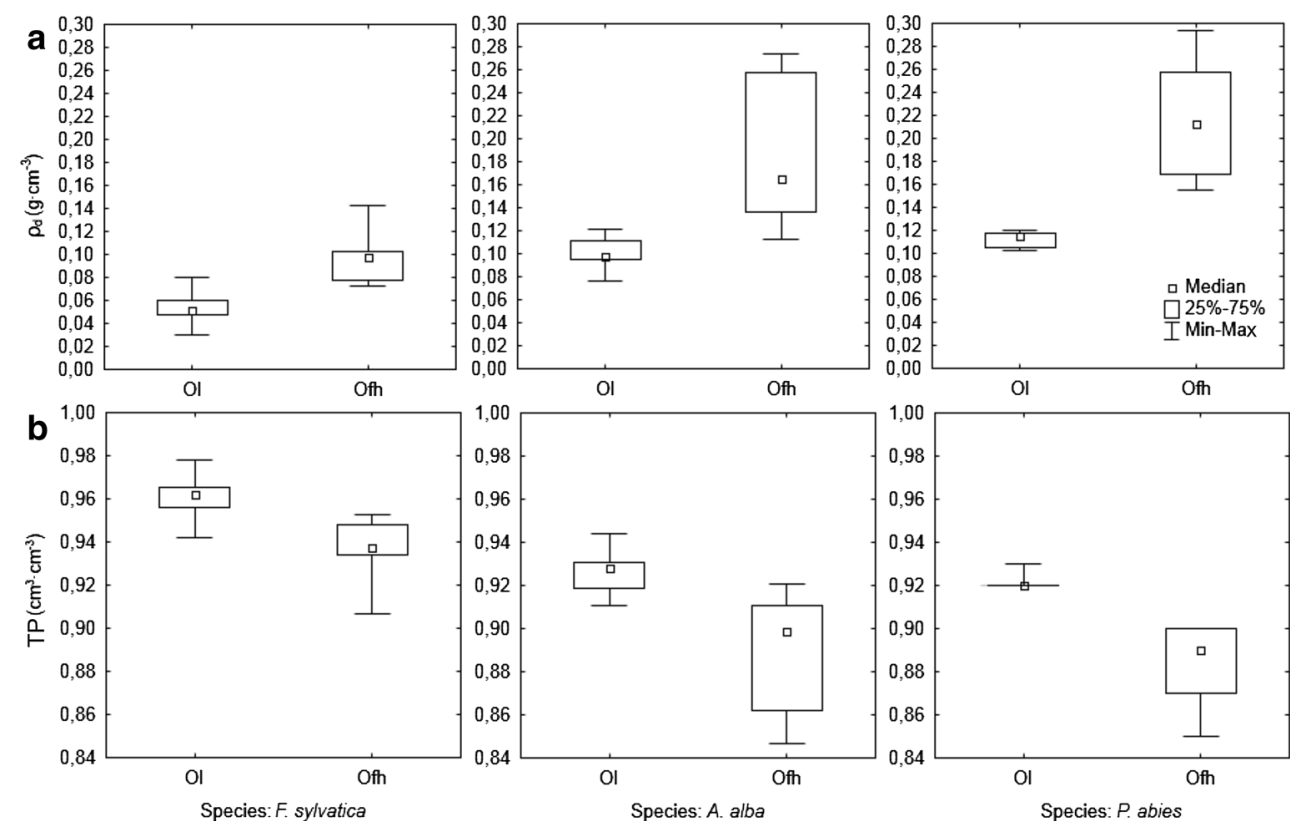

horizons. Bulk density $\rho_{\mathrm{d}}$ of spruce litter was on average of $0.112 \mathrm{~g} \cdot \mathrm{cm}^{-3}$. This value was on average by $0.009 \mathrm{~g} \cdot \mathrm{cm}^{-3}$ higher than the average density $\rho_{\mathrm{d}}$ of fir litter and more than double the density of beech litter (Fig. 4a). Similarly, bulk density $\rho_{\mathrm{d}}$ of the Ofh horizons of spruce stands was on average $0.029 \mathrm{~g} \cdot \mathrm{cm}^{-3}$ higher than the density of fir detritus horizons and more than twice higher than the density of the Ofh horizons of beech stands.

The highest total porosity TP among all layers of the examined stands characterized beech litter (Fig. 4b). It was on average $0.04 \mathrm{~cm}^{3} \cdot \mathrm{cm}^{-3}$ larger in comparison with fir and spruce litter. Also, the Ofh horizons of fir and spruce stands had their total porosity TP on average $0.05 \mathrm{~cm}^{3} \cdot \mathrm{cm}^{-3}$ lower in relation to the Ofh horizons of beech stands.

Bulk density and total porosity are strongly dependent on the content of organic matter in soil (Kucza 2007; Gajić 2013). While this relationship works for the layers of mineral soil, in the case of ectohumus, it raises some doubts. For example, the average share of organic matter $C_{\mathrm{o}}$ in the fresh forest litter sublevels of fir, beech and spruce stands was at a similar level and ranged from 97.7 to $98.3 \%$ (Fig. 3a). This suggests that the values of density $\rho_{\mathrm{d}}$ of these horizons should be similar in all of the studied stands. However, as is apparent from Fig. 5, the dependence of density $\rho_{\mathrm{d}}$ of the $\mathrm{Ol}$ and Ofh horizons and of the whole ectohumus $(\mathrm{O})$ in spruce, fir and beech stands on the content of organic matter $C_{\mathrm{o}}$ proceeds in different ways, with the most noticeable differences between softwood (fir and spruce) ectohumus and deciduous ectohumus. It follows that bulk density $\rho_{\mathrm{d}}$ of the organic horizons of forest soils is largely determined by the botanical composition and morphology of organic debris, forming these layers.

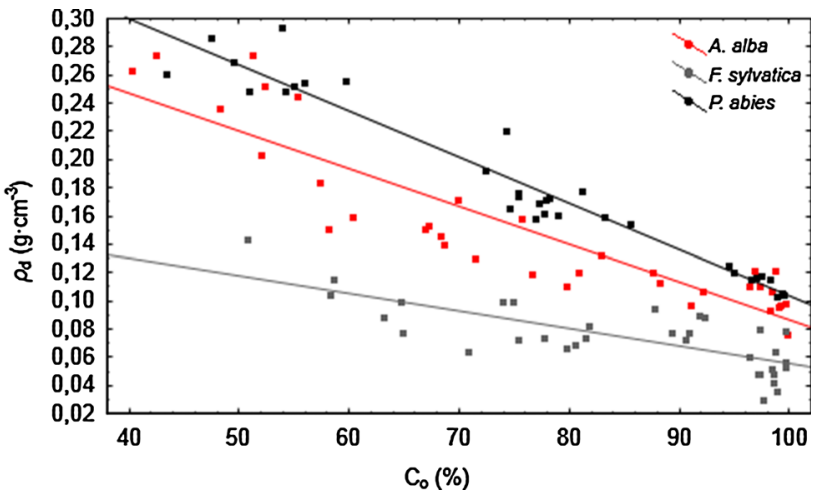

Fig. 5 The dependence of bulk density $\rho_{\mathrm{d}}$ of fir, beech and spruce ectohumus on the organic matter content $C_{\mathrm{o}}$

This relationship is described by the following formula, explaining $88 \%$ of the variation of this feature (Table 3):

$\rho_{\mathrm{d}}=0.374-0.003 \times C_{\mathrm{o}}-0.052 \times$ Fir $-0.086 \times$ Beech

where $\rho_{\mathrm{d}}$ is the bulk density $\left(\mathrm{g} \cdot \mathrm{cm}^{-3}\right) ; C_{\mathrm{o}}$ is the organic matter content (wt\%); Fir and Beech are species-related variables, assuming the values of 0 or 1 , depending on the species for which bulk density is calculated. If it is for spruce, then both variables (Fir and Beech) assume the 0 value.

Evaluation of significance of the parameters of Eq. 8 is shown in Table 3. On the basis of statistic $t$, it was found that the parameters of the analyzed model of regression are substantially different from 0 . Partial correlation values confirm that a large part of the variation of density $\rho_{\mathrm{d}}$ of 
Table 3 The parameters of Eq. 8 and evaluation of their significance

\begin{tabular}{lllrlllll}
\hline Variables & $\begin{array}{l}\text { Parameter } \\
\text { value }\end{array}$ & SE & $\begin{array}{l}\text { Statistic } \\
t \text { value }\end{array}$ & $\begin{array}{l}\text { Probability } \\
\text { level }\end{array}$ & $\begin{array}{l}\text { Partial } \\
\text { correlation }\end{array}$ & VIF & $R_{\text {adj }}^{2}$ & $\begin{array}{l}\text { SE of } \\
\text { estimation }\end{array}$ \\
\hline Free term & 0.374 & 0.011 & 33.77 & 0.00 & - & - & 0.88 & 0.023 \\
$C_{\mathrm{o}}$ & -0.003 & 0.000 & -18.68 & 0.00 & -0.88 & 1.00 & & \\
Fir & -0.052 & 0.006 & -5.59 & 0.00 & -0.70 & 1.08 & & \\
Beech & -0.086 & 0.006 & -14.77 & 0.00 & -0.83 & 1.10 & & \\
\hline
\end{tabular}
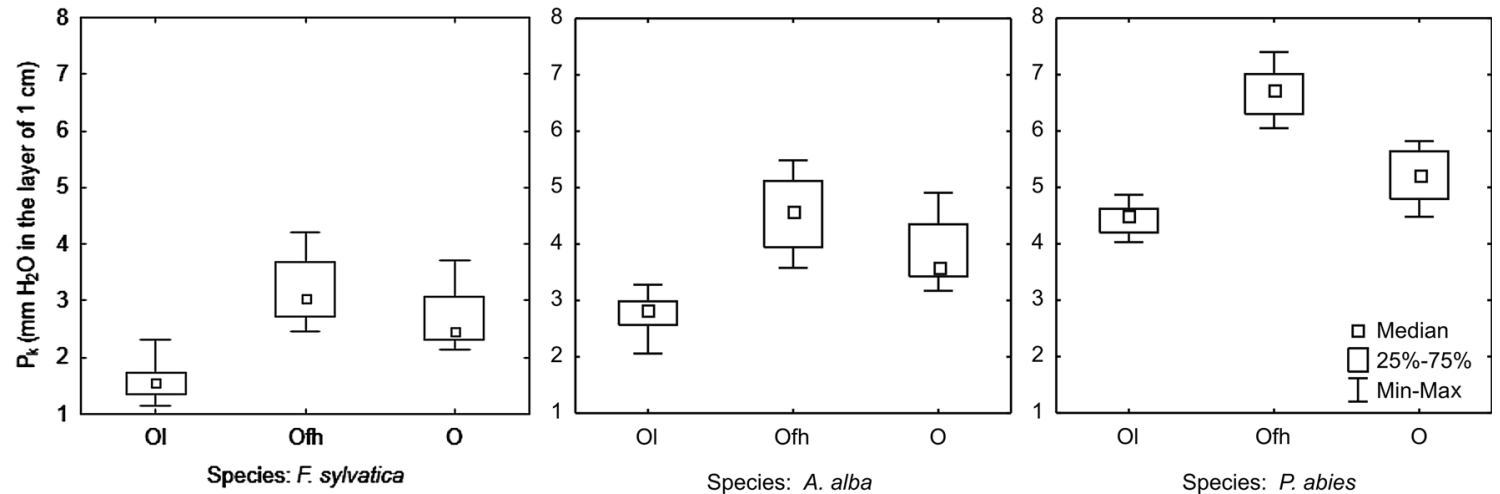

Fig. 6 The range of variation of capillary capacity $P_{\mathrm{k}}$ of the $\mathrm{Ol}$ and Ofh horizons and the whole ectohumus $(\mathrm{O})$, formed under beech, fir and spruce stands

ectohumus is explained by the content of organic matter $C_{\mathrm{o}}$ and by the botanical composition of organic debris. On the basis of the VIF, it may be stated that the independent variables applied in Eq. 8 are not redundant, as confirmed by their direct relationship with bulk density $\rho_{\mathrm{d}}$ (Table 3 ).

\section{Capillary capacity}

Figure 6 illustrates the distribution of variability of capillary capacity $P_{\mathrm{k}}$ determined for the fir and beech ectohumus (O) and its particular sublevels (Ol, Ofh), in comparison with the organic levels of spruce stands (Kucza 2007).

Capillary capacity $P_{\mathrm{k}}$ of the litter of individual stands assumed much lower values than capacity $P_{\mathrm{k}}$ of the Ofh horizons (Fig. 6). Capillary capacity $P_{\mathrm{k}}$ of the $\mathrm{Ol}$ horizon differed significantly between beech, fir and spruce stands, assuming average values equal to $1.60( \pm 0.10)$, $2.76( \pm 0.11)$ and $4.44( \pm 0.10) \mathrm{mm}$, respectively. Significant differences in capillary capacity $P_{\mathrm{k}}$ between particular species were also found in the detritus Ofh horizons. As in the case of litter, the smallest capacity $P_{\mathrm{k}}$ characterized the beech detritus (Ofh) horizons, wherein their capillary capacity was on average $1.39 \mathrm{~mm}$ lower in comparison with the Ofh horizons of fir stands and over twice lower in comparison with the corresponding layers in spruce stands (Fig. 6). The consequence of differences in the capillary capacity of the $\mathrm{Ol}$ and Ofh horizons of individual species was also different in capacity $P_{\mathrm{k}}$ of the whole organic layer
(O). It was found that, among all of the studied species, the largest capillary capacity characterized spruce ectohumus (Fig. 6).

Since the layer of litter is made up of dead parts of plants which are not yet adjacent to each other, in comparison with the lower lying horizons of soil, litter has the lowest bulk density, and hence the lowest water-retaining capacity (Suliński 1993). It should be noted, however, that capillary capacity $P_{\mathrm{k}}$ of the $\mathrm{Ol}$ horizon differed significantly between beech, fir and spruce stands (Fig. 6). Similarly, Zhang et al. (2006) showed that the water storage capacity of the litter of coniferous stands is greater than that of deciduous ones. Leuschner (1998) showed differences in the formation of the water storage capacity of organic horizons between beech, oak and pine stands. Walsh and Voigt (1977) found that beech leaves retain more water than pine needles. According to Sato et al. (2004), the litter of L. edulis stores more water than the litter of $C$. japonica. Tsiko et al. (2012) showed that the water storage capacity of the litter in the B. speciformis stand and litter formed under herbaceous vegetation amounted to 1.8 and $1.5 \mathrm{~mm}$, respectively. According to Gerrits (2010), cedar litter is characterized by an almost twice smaller water storage capacity $(1.0 \mathrm{~mm})$ than beech litter $(1.8 \mathrm{~mm})$. Putuhena and Cordery (1996) found the water storage capacity of 2.28 and $1.38 \mathrm{~mm}$, respectively, for the litter of pine and eucalyptus.

Water retention of litter depends on its structure and the size of the pore space, determined by the size of organic 
Table 4 The parameters of Eq. 9 and evaluation of their significance

Table 5 The parameters of Eq. 10 and evaluation of their significance

\begin{tabular}{lccccllll}
\hline Variables & $\begin{array}{l}\text { Parameter } \\
\text { value }\end{array}$ & SE & $\begin{array}{l}\text { Statistic } \\
t \text { value }\end{array}$ & $\begin{array}{l}\text { Probability } \\
\text { level }\end{array}$ & $\begin{array}{l}\text { Partial } \\
\text { correlation }\end{array}$ & VIF & $R_{\text {adj }}^{2}$ & $\begin{array}{l}\text { SE of } \\
\text { estimation }\end{array}$ \\
\hline Free term & 2.83 & 0.20 & 13.97 & 0.00 & - & - & 0.91 & 0.49 \\
$\rho_{\mathrm{d}}$ & 16.18 & 1.01 & 16.08 & 0.00 & 0.85 & 1.24 & & \\
Fir & -1.50 & 0.12 & -12.04 & 0.00 & -0.78 & 1.11 & & \\
Beech & -1.60 & 0.16 & -9.93 & 0.00 & -0.71 & 1.50 & & \\
\hline
\end{tabular}

\begin{tabular}{lccclllll}
\hline Variables & $\begin{array}{l}\text { Parameter } \\
\text { value }\end{array}$ & SE & $\begin{array}{l}\text { Statistic } \\
t \text { value }\end{array}$ & $\begin{array}{l}\text { Probability } \\
\text { level }\end{array}$ & $\begin{array}{l}\text { Partial } \\
\text { correlation }\end{array}$ & VIF & $R_{\text {adj }}^{2}$ & $\begin{array}{l}\text { SE of } \\
\text { estimation }\end{array}$ \\
\hline Free term & 40.77 & 2.19 & 18.64 & 0.00 & - & - & 0.91 & 0.49 \\
TP & -39.08 & 2.44 & -16.01 & 0.00 & -0.85 & 1.43 & & \\
Fir & -1.62 & 0.12 & -13.09 & 0.00 & -0.80 & 1.10 & & \\
Beech & -1.26 & 0.18 & -7.20 & 0.00 & -0.59 & 1.72 & & \\
\hline
\end{tabular}

Table 6 The parameters of Eq. 11 and evaluation of their significance

\begin{tabular}{lccclllll}
\hline Variables & $\begin{array}{l}\text { Parameter } \\
\text { value }\end{array}$ & SE & $\begin{array}{l}\text { Statistic } \\
t \text { value }\end{array}$ & $\begin{array}{l}\text { Probability } \\
\text { level }\end{array}$ & $\begin{array}{l}\text { Partial } \\
\text { correlation }\end{array}$ & VIF & $R_{\text {adj }}^{2}$ & $\begin{array}{l}\text { SE of } \\
\text { estimation }\end{array}$ \\
\hline Free term & 1.42 & 0.27 & 5.32 & 0.00 & - & - & 0.93 & 0.43 \\
$W_{\mathrm{NC}}$ & 0.12 & 0.01 & 18.31 & 0.00 & 0.89 & 1.11 & & \\
Fir & -0.91 & 0.14 & -6.58 & 0.00 & -0.58 & 1.42 & & \\
Beech & -2.56 & 0.13 & -19.91 & 0.00 & -0.91 & 1.43 & & \\
\hline
\end{tabular}

molecules (Kramer and Boyer 1995; Homa and Osuch 2009). Given the low density $\rho_{\mathrm{d}}$ (Fig. 4a), high porosity TP (Fig. 4b) and the relatively large size of beech leaves, the low capillary capacity $P_{\mathrm{k}}$ of beech organic horizons may be due to the large size of the pores, preventing the retention of precipitation in areas formed between particular components which form part of these levels. This suggests that the dominant role in rainfall retention by these levels is played by water adsorption and absorption by organic molecules. In the case of softwood ectohumus, both the spruce litter and the Ofh horizon as well as the whole ectohumus $(\mathrm{O})$ retained much more water than the organic horizons of fir stands (Fig. 6) although the differences in bulk density $\rho_{\mathrm{d}}$ and total porosity TP of the $\mathrm{Ol}$ and Ofh horizons were relatively small between those stands (Fig. 4). As fir produces flat needles with a length of $1.5-3.0 \mathrm{~cm}$, and spruce is characterized by narrow and four-sided needles with a length of 1.0-2.5 cm (Seneta and Dolatowski 2004), it can be assumed that with the same porosity TP, the size of the pores formed in the organic horizons of forest soils will vary depending on the size, and thus the botanical composition of organic debris, forming part of these layers. Therefore, in addition to the absorption and adsorption of water by organic matter, rainwater retention by the organic layers of coniferous stands will probably largely depend on the system of capillaries being formed between the organic remains, and this role of the capillaries will be the greater, the finer litterfall reaches the forest floor.

The dependence of capillary capacity on bulk density and botanical composition of organic debris, belonging to beech, fir and spruce ectohumus, is described by the equation which explains $91 \%$ of the variability of this trait (Table 4):

$P_{\mathrm{k}}=2.83+16.18 \times \rho_{\mathrm{d}}-1.50 \times$ Fir $-1.60 \times$ Beech

where $P_{\mathrm{k}}$ is the capillary capacity $\left(\mathrm{mm} \mathrm{H}_{2} \mathrm{O}\right.$ in the layer of $1 \mathrm{~cm}) ; \rho_{\mathrm{d}}$ is the bulk density $\left(\mathrm{g} \cdot \mathrm{cm}^{-3}\right) ;$ Fir and Beech are species variables, adopting the value of 0 or 1 depending on the species for which the capillary capacity is calculated.

Similarly, the dependence of the capillary capacity $P_{\mathrm{k}}$ of the organic horizons on total porosity TP and the origin of organic debris is described by an equation explaining $91 \%$ of the variation of this trait (Table 5):

$P_{\mathrm{k}}=40.77-39.08 \times \mathrm{TP}-1.62 \times$ Fir $-1.26 \times$ Beech

Assessment of significance of the parameters of Eqs. 9 and 10 is presented in Tables 4 and 5, respectively. Partial correlation values of both equations confirm that a large part of capillary capacity $P_{\mathrm{k}}$ is explained by the botanical composition of the organic matter which is comprised in ectohumus. 
The chemical composition and value of the $\mathrm{C}: \mathrm{N}$ ratio of litterfall are mainly determined by stand species composition and habitat (Gonet et al. 2007; Zaujec 2007). Variation in bulk density and total porosity of the different ectohumus sublevels, progressing with depth in the soil profile, is determined by the variability of organic material (decomposition), which affects both the hydrological and the thermal characteristics of these levels (Sharratt 1997). The dependence of capillary capacity $P_{\mathrm{k}}$ of organic horizons on decomposition index $W_{\mathrm{NC}}$ and the origin of organic debris is described by the equation which explains $93 \%$ of the variability of this trait (Table 6):

$P_{\mathrm{k}}=1.42+0.12 \times W_{\mathrm{NC}}-0.91 \times$ Fir $-2.56 \times$ Beech

where $P_{\underline{k}}$ is the capillary capacity $\left(\mathrm{mm} \mathrm{H}_{2} \mathrm{O}\right.$ in the layer of $1 \mathrm{~cm}$ ); $W_{\mathrm{NC}}$ is the index of organic matter decomposition; Fir and Beech are species-related variables, assuming the values of 0 or 1 depending on the species for which the capillary capacity is calculated.

Evaluation of significance of the parameters of Eq. 11 is presented in Table 6 . Since the type of substrate entering the soil as a result of litter accumulation or as a result of the death of underground parts is an important element influencing the rate of decomposition of dead organic matter (Drewnik 2006), the high significance of Eq. 11 (Table 6) confirms that susceptibility to decomposition, and consequently the advancement of processes of decomposition of organic matter of different origins, is important factor determining the retention properties of the upper layers of forest soils.

\section{Summary and conclusions}

The present study confirms the theory stating that, by providing litterfall with different physical and chemical properties, the stand species composition affects the structure of the organic horizons of forest soils, and through this, structure plays a significant role in forming the retention capacities of forest soils. It has been shown that morphological differentiation of falling organic debris of various origins, its susceptibility to decomposition and the advancement of the processes of organic matter decomposition significantly affect the capillary capacity of the surface layers of forest soils. It has been found that the organic cover of spruce stands, as compared to beech and fir stands, is characterized by the highest water storage capacity. The reported differences between particular species concerning the water storage capacity of ectohumus suggest that through rational forest management measures, connected with the regulation of stand species composition and the introduction of admixture species, it will be possible to improve the retention capability of forest soils.
Acknowledgments The authors would like to thank two anonymous reviewers for the thorough assessment of the present paper and for their many valuable and helpful suggestions.

Open Access This article is distributed under the terms of the Creative Commons Attribution License which permits any use, distribution, and reproduction in any medium, provided the original author(s) and the source are credited.

\section{References}

Bernard JM (1963) Forest floor moisture capacity of the New Jersey pine barrens. Ecology 44(3):574-576

Binkley D (1995) The influence of tree species on forest soils: processes and patterns. In: Mead DJ, Cornforth IS (eds) Proceedings of the trees and soil workshop. Agronomy Society of New Zealand special publication no. 10. Lincoln University Press, Canterbury, pp 1-33

Coûteaux MM, Sarmiento L, Bittner P, Acevedo D, Thièry JM (2002) Decomposition of standard plant material along an altitudinal transect $(65-3968 \mathrm{~m})$ in the tropical Andes. Soil Biol Biochem 34:69-78

Drewnik M (2006) Właściwości stropowych poziomów próchnicznych gleb polskiej części Karpat. Roczniki Bieszczadzkie 14:221-235

Dziadowiec H, Pokojska U, Prusinkiewicz Z (2004) Materia organiczna, koloidy i roztwór glebowy jako przedmiot badań specjalistycznych. In: Bednarek R, Dziadowiec H, Pokojska U, Prusinkiewicz Z (eds) Badania ekologiczno-gleboznawcze. PWN, Warszawa, pp 113-246

Gajić B (2013) Physical properties and organic matter of fluvisols under forest, grassland, and 100 years of conventional tillage. Geoderma 200:114-119

Gerrits AMJ (2010) The role of interception in the hydrological cycle. University of Technology, the Netherlands

Gerrits AMJ, Savenije HHG, Hoffmann L, Pfister L (2006) Measuring forest floor interception in a beech forest in Luxembourg. Hydrol Earth Syst Sci Discuss 3:2323-2341

Golding DL, Stanton CR (1972) Water storage in the forest floor of subalpine forests of Alberta. Can J For Res 2(1):1-6

Gonet SS (2007) Ochrona zasobów materii organicznej gleb. In: Gonet SS, Markiewicz M (eds) Rola materii organicznej w środowisku. Pol Tow Subst Hum, Wrocław, pp 7-29

Gonet SS, Dębska B, Zaujec A, Banach-Szot M, Szombáthová N (2007) Wpływ gatunku drzew i warunków glebowo-klimatycznych na właściwości próchnicy gleb leśnych. In: Gonet SS, Markiewicz M (eds) Rola materii organicznej w środowisku. Pol Tow Subst Hum, Wrocław, pp 61-98

Greiffenhagen A, Wessolek G, Facklam M, Renger M, Stoffregen H (2006) Hydraulic functions and water repellency of forest floor horizons on sandy soils. Geoderma 132:182-195

Grelewicz A, Plichta W (1983) Water absorption of xeromor forest floor samples. For Ecol Manag 6:1-12

Grelewicz A, Plichta W (1985) Water absorption in samples of different types of forest humus. For Ecol Manag 10:1-11

Homa A, Osuch B (2009) Characteristics of the forest floor water retention in the Carpathian experimental catchment basin of the Trzebunia brook. J Water Land Dev 13a:5-17

Ilek A (2014) Znaczenie materii organicznej w kształtowaniu zdolności retencyjnych gleb leśnych pod drzewostanami jodłowymi i bukowymi na terenie Beskidu Makowskiego. Dissertation, University of Agriculture in Cracow

Johansson MB (1994) Decomposition rates of Scots pine needle litter related to site properties, litter quality and climate. Can J For Res 24(9):1771-1781 
Jonczak J (2013) Dynamics, structure and properties of plant litterfall in a 120-year old beech stand in Middle Pomerania between 2007-2010. Soil Sci Annu 64(1):8-13

Keith DM, Johnson EA, Valeo C (2010a) A hillslope forest floor (duff) water budget and the transition to local control. Hydrol Process 24:2738-2751. doi:10.1002/hyp.7697

Keith DM, Johnson EA, Valeo C (2010b) Moisture cycles of the forest floor organic layer ( $\mathrm{F}$ and $\mathrm{H}$ layers) during drying. Water Resour Res 46:W07529. doi:10.1029/2009WR007984

Kiss KA, Gribovski Z, Kalicz P (2005) Rainfall interception by forest canopy and forest litter in Tyree different forest ecosystems AT the ekstern border of the Alps. Geophys Res Abstr 7:05430

Kodešová R, Pavlů L, Kodeš V, Žigová A, Nikodem A (2007) Impact of spruce forest and grass vegetation cover on soil micromorphology and hydraulic properties of organic matter horizon. Biol Bratisl 62(5):565-568

Kowalkowski A (1994) Metodyka badań ilościowo-jakościowych cech opadu organicznego na Stacjach Geoekologicznych Święty Krzyż i Góra Malik. Monitoring Środowiska Regionu Świętokrzyskiego 2. Kieleckie Towarzystwo Naukowe, Kielce, pp 47-52

Kramer PJ, Boyer JS (1995) Water relations of plants and soils. Academic Press, New York

Kucza J (2003a) Teoretyczne i praktyczne aspekty metodyki badań nad zatrzymywaniem wody opadowej przez poziomy organiczne gleb leśnych w warunkach symulowanych opadów. Acta Agr Silv ser Silv 41:25-37

Kucza J (2003b) Laboratoryjne badania zatrzymywania wody w poziomach organicznych i mineralnych gleb wybranych dolnoreglowych drzewostanów świerkowych w Beskidzie Śląskim. Część I Wpływ długości czasu przesychania próbki organicznej na jej zdolność zatrzymywania wody. Acta Agr Silv ser Silv 41:39-58

Kucza J (2003c) Laboratoryjne badania zatrzymywania wody w poziomach organicznych i mineralnych gleb wybranych dolnoreglowych drzewostanów świerkowych w Beskidzie Śląskim. Część II Relacje między zdolnością zatrzymywania wody a gęstością objętościową próbki. Acta Agr Silv ser Silv 41:59-75

Kucza J (2007) Właściwości hydrologiczne materii organicznej gleb leśnych na przykładzie gleb pod świerczynami istebniańskimi. Zesz Nauk AR Krak, Ser Rozpr 442, University of Agriculture, Cracow

Kucza J, Suliński J (2000) Relacje pomiędzy porowatością kapilarną a gęstością objętościową i kurczliwością gruntów o różnej zawartości części organicznych, występujących na terenie zlewni doświadczalnej Potok Dupniański w Beskidzie Śląskim. Acta Agr Silv ser Silv 38:91-106

Kucza J, Urbaś J (2005) Water absorption of organic matter taken from horizons of ectohumus of forest soils under Norway spruce stands. EJPAU Ser For 8(4):50

Laurén A, Mannerkoski H (2001) Hydraulic properties of mor layers in Finland. Scand J For Res 16:429-441

Leuschner Ch (1998) Water extraction by tree fine roots in the forest floor of the temperate Fagus-Quercus forest. Ann Sci For $55: 141-157$

Li X, Niu J, Xie B (2013) Study on hydrological functions of litter layers in North China. PLoS One 8(7):e70328

Maciaszek W, Zwydak M (1996) Przekształcanie górskich gleb porolnych przez przedplony sosnowe. Cz I Przemiany morfologii profilu i właściwości fizycznych gleb. Acta Agr Silv ser Silv 34:67-79

Naeth MA, Bailey AW, Chanasyk DS, Pluth DJ (1991) Water holding capacity of litter and soil organic matter in mixed prairie and fescue grassland ecosystems of Alberta. J Range Manag 44(1):13-17

Neris J, Tejedor M, Rodriguez M, Fuentes J, Jiménez C (2013) Effect of forest floor characteristics on water repellency, infiltration, runoff and soil loss in Andisols of Tenerife (Canary Islands, Spain). Catena 108:50-57

Niewinna M (2010) Wielkość opadu i tempo rozkładu ściółki w wybranych drzewostanach Bieszczadów. Roczniki Bieszczadzkie 18:59-73

Olszowska G (2011) Zmienność biochemiczna gleb siedlisk leśnych na granicy zasięgu buka zwyczajnego Fagus sylvatica L. w Polsce. Leśne Prace Badawcze 72(4):321-328

Park A, Friesen P, Sarmiento Serrud AA (2010) Comparative water fluxes through leaf litter of tropical plantation trees and the invasive grass Saccharum spontaneum in the Republic of Panama. J Hydrol 383:167-178

Parzych A, Trojanowski J (2009) Struktura i dynamika opadu organicznego w wybranych drzewostanach Słowińskiego Parku Narodowego w latach 2003-2005. Leśne Prace Badawcze 70(1):41-48

Prusinkiewicz Z, Kosakowski A (1986) Zwilżalność próchnicy jako czynnik kształtujący gospodarkę wodną gleb leśnych. Rocz Gleb 37(1):3-23

PUL (2008) Plan Urządzania Lasu dla Nadleśnictwa Myślenice, na okres gospodarczy od 1 stycznia 2008r. do 31 grudnia 2017r

Putuhena WM, Cordery I (1996) Estimation of interception capacity of the forest floor. J Hydrol 180:283-299

Raaflaub LD, Valeo C (2008) Assessing factors that influence spatial variations in duff moisture. Hydrol Process 22:2874-2883

Raaflaub L, Valeo C (2009) Hydrological properties of duff. Water Resour Res 45. doi:10.1029/2008WR007396

Sato Y, Kumagai T, Kume A, Otsuki K, Ogawa S (2004) Experimental analysis of moisture dynamics of litter layers-the effects of rainfall conditions and leaf shapes. Hydrol Process 18:3007-3018

Schaap MG, Bouten W, Verstraten JM (1997) Forest floor water content dynamics in a Douglas fir stand. J Hydrol 201:367-383

Seneta W, Dolatowski JD (2004) Dendrologia. PWN, Warszawa

Sharafatmandrad M, Bahremand A, Mesdaghi M, Barani H (2010) The role of rainfall and light interception by litter on maintenance of surface soil water content in an arid rangeland (Khabr National Park, southeast of Iran). Desert 15:53-60

Sharratt BS (1997) Thermal conductivity and water retention of a black spruce forest floor. Soil Sci 162:576-582

Simmons IG (1974) The ecology of natural resources. Edward Arnold, London

StatSoft (2011) STATISTICA (data analysis software system), version 10. www.statsoft.com

Suliński J (1993) Modelowanie bilansu wodnego w wymianie między atmosferą, drzewostanem i gruntem przy użyciu kryteriów ekologicznych. Zesz Nauk AR Krak, Ser Rozpr 179

Tobiašová E (2011) The effect of organic matter on the structure of soils of different land uses. Soil Tillage Res 114:183-192

Trampler T, Kliczkowska A, Dmyterko E, Sierpińska A (1990) Regionalizacja przyrodniczo-leśna na podstawach ekologicznofizjograficznych. PWRiL, Warszawa

Tsiko CT, Makurira H, Gerrits AMJ, Savenije HHG (2012) Measuring forest floor and canopy interception in a savannah ecosystem. Phys Chem Earth Parts A/B/C 47:122-127

Walsh RPD, Voigt PJ (1977) Vegetation litter: an underestimated variable in hydrology and geomorphology. J Biogeogr 4:253-274

Zaujec A (2007) Funkcje materii organicznej w obiegu związków węgla i żyzności gleb. In: Gonet SS, Markiewicz M (eds) Rola materii organicznej w środowisku. Pol Tow Subst Hum, Wrocław, pp 31-46

Zhang Z, Chen Y, Zhang Z, Cui H, Lei Y, Wang D, Sui J (2006) Water-holding characteristics of litter in different forests at the Lianxiahe watershed. Front For China 4:413-418

Zhang Z, Lei Y, Su K, Wang G, Wang D, Ma H (2009) Hydrological characteristics of litter in different forest succession stages at Liuxihe watershed, southern China. Front For China 4(3):317-322 